\title{
Effect of castration and docking of lambs on maintenance behaviour and cortisol level
}

\author{
H.H. Emeash, A.S. Mostafa, N. M. Abdel-Azem \\ Department of Hygiene, Management and Zoonoses, Faculty of Veterinary Medicine, Beni-suef \\ University, Beni-Suef 62511, Egypt.
}

\begin{abstract}
Thirty apparently healthy lambs with average weight and age of $5.8 \pm 0.5 \mathrm{~kg}$ and $15 \pm 1.6$ days respectively were chosen in Sids Agricultural Research Station belonging to Animal Production Research Institute in Beni-Suef governorate to investigate the effect of castration and docking on maintenance behaviour and blood cortisol level during and after such operations. Lambs were classified into castration $(n=10)$, docking $(n=10)$ and control $(n=10)$ groups. The results revealed that castration and docking could significantly affect the behaviours of standing idle, recumbency, sleep, suckling and ingestion in lambs. Moreover, blood cortisol level was significantly $(\mathbf{p}<0.05)$ increased after operation in castrated and docked lambs as compared to the time before, at operation and 3 hours after operation.
\end{abstract}

Sheep raising is important for farmers and breeders in many economical aspects, given that sheep can give milk and its products, meat, wool and hide.

In extensive sheep farming systems, male lambs may reach puberty before slaughter. Consequently, castration of males in the first few days or weeks after birth is often a standard management procedure to prevent disruption in the flock through sexual activity of young males (mounting activity, flehmen and nosing (Appleby, 1986), unwanted pregnancies and indiscriminate breeding (Baird and Wolfe, 1998; Archer, 2004). Castration has been also practiced by man for many centuries as a mean of reducing aggression (head pushing, butting and threat) and ease management(Mowlem, 1988).In addition, wethers have more weight in the desirable cuts of the hind quarters as contrasted to the ram (Haddad et al., 2006).

The main reason of docking is to ensure health and sanitary conditions of the skin. A lamb with a tail is more likely to have manure built up between his body and tail, not only creating an extremely wet, dirty breeding ground for disease, but also a long tail hampers the ram's breeding efforts and makes it more difficult to assist a ewe at lambing (Outhouse, 1987).

Docking and castration are considered as severe stressors that lambs may encounter as a part of routine husbandry (Turner et al., 2006) which indicated by behavioural and physiological changes indicating a considerable pain at all ages (Wood et al., 1991; Cottrell and Molony, 1995; Pawelek and Croney, 2003) as well as the level of blood cortisol was increased following such operations as shown by (Shutt et al., 1988; Wood et al., 1991; Kent et al., 1993; Rhodes III et al., 1994; Lester et al., 1996; Dinniss et al., 1997; Diniss et al., 1999; Marai and Bahgat, 2003).

Bloodless castration method produces considerable acute pain and most of that pain occurs during and immediately after crushing the skin and spermatic cord which will be reflected on the behavioural changes that occur (Thornton and Waterman-Pearson, 1999). Furthermore, some behavioural changes could be observed in lambs which are castrated and docked by the use of clamp (Mellor and Stafford, 2000; Mellemaa et al., 2006; Susanne et al., 2007).

The main object of this study is to investigate the effect of castration and docking of lambs on their maintenance behaviour and changes that occur in blood cortisol level during and after such operations.

\section{Materials and methods}

This study was carried out in Sids Agricultural Research Station belonging to Animal Production Research Institute in Beni-Suef governorate.

Animals and management. The flock consists of 175 Ossimi and 145 Saidi sheep which are housed in open fronted pens with a stocking density of 1.5 to $2 \mathrm{~m} 2 /$ head. Sheep were fed on a processed feed in addition to hay and straw and 
watered twice daily in the morning and late afternoon. Pregnant ewes were separated into lambing pens before expected lambing by one week. A total number of thirty apparently healthy lambs with average weight and age of $5.8 \pm 0.5 \mathrm{~kg} 15 \pm 1.6$ days respectively were chosen for castration and docking and classified into castration $(\mathrm{n}=10)$, docking $(\mathrm{n}=10)$ and control $(\mathrm{n}=10)$ groups.

Castration and docking. Ten male lambs were non surgically castrated in this experiment by using bloodless castrating clamp (Burrdizzo) which crush and cause irreversible damage to the vessels supplying the testes (Thronton and Waterman-Pearson, 1999). On the other hand, ten female lambs were docked by surgical amputation of the tail using sharp scalpel after crushing the dock for 2 minutes by using of Burrdizzo to reduce the incidence of hemorrhage as described by (Susan, 2007).

Behaviour recording and measurements. Behavioural patterns were recorded by direct personal observation directly after application of castration and docking for 180 minutes with an interval of 2 minutes as a frequency as described by (Molony et al., 1997; Molony and Kent, 1997). The patterns were recorded for comfort behaviour (standing idle, recumbency and sleep), body care behaviour (grooming), eliminative behaviour (defecation and urination) and feeding behaviour (suckling, trial suckling, ingestion and drinking water).

Blood samples and assay. About $5 \mathrm{ml}$ of blood was obtained from the jugular vein of each lamb in a clean dry centrifuge tube before, at the time of, $1 \mathrm{hr}$ and $3 \mathrm{hrs}$ after castration and docking as mentioned by (Molony and Kent, 1997; Kent et al., 1993). Samples were left standing for about 15 minutes till complete clotting and put in the refrigerator for 4 hours to aid in clot separation, then centrifuged at 3000 r.p.m. for 15 minutes for serum separation. After that serum is pipetted and put into labled eppindorf tubes and kept by deep freezing at $-20^{\circ} \mathrm{C}$ till assayed. Serum samples were analyzed for cortisol hormone by the use of Competitive Colorimetric Immunoenzymatic method described by (Rolleri et al., 1976).

Statistical analysis. Results were statistically analyzed by the use of one way ANOVA according to (Snedecor and Cochran, 1989).

\section{Results and Discussion}

Table (1) showed the effect of castration and docking on comfort and body care behaviour of lambs and revealed that behaviour of standing idle was significantly $(\mathrm{p}<0.05)$ higher in castrated (13.0) and docked (11.4) lambs than control ones (4.4). This may occur as a way to minimize stimulation of sensitized nociceptors, as found in damaged or inflamed tissues. Such result is parallel to that reported by (Shutt et al., 1988; Mellor and Murray, 1989; Molony et al., 1995; Lester et al., 1996) but do not support that obtained by (McGlone et al., 1993) who observed that standing time was increased in intact animals than those castrated. Additionally, there is a significantly $(\mathrm{p}<0.05)$ higher frequency of recumbency in castrated (17.0) than docked (8.7) and control (9.0) lambs. This may occur as a comfortable position to relief pain. This result is similar to that obtained by (Saleem et al., 2003). Furthermore, there was a significant $(\mathrm{p}<0.05)$ decrease in frequency of sleep in docked (2.9) than castrated (7.5) and control (8.4) lambs. This may result from the pain produced by castration and docking procedures.

Opp (1995) indicated that sleep is a fundamental CNS process that is regulated by a complex interaction between neural and humoral systems and altered in response to a variety of stressors. With reference to body care behaviour, the results clarified that there was no significant difference between castrated, docked and control groups in frequency of the grooming, defecation and urination behaviours.

Concerning the effect of castration and docking on feeding behaviour as shown in Table $(2)$, there was a significant $(\mathrm{P}<0.05)$ decrease in frequency of suckling behaviour in docked (1.0) and castrated (2.4) than control (4.8) lambs. This may be related to the distress caused by pain reflected from the procedure. This result is in accordance with that of (Saleem et al., 2003), while there was no significant difference in trial suckling frequency between the studied groups. On the other hand, there was a significant $(p<0.05)$ increase in frequency of feeding behaviour in control group (3.4) than in those castrated or docked which was not observed. Such results may be also due to the stressful and painful effect encountered in lambs subjected to the procedure. The noxious stimulus results in a decrease in animal's general physical activity or causes some activities that occur infrequently to disappear (Mellor et al., 2000). Moreover, there was no significant difference in drinking behaviour between the studied groups.

The level of blood cortisol as affected by castration and docking was illustrated in Table 
Table (1): Effect of castration and docking on comfort, body care and eleminative behaviours in lambs.

\begin{tabular}{|c|c|c|c|c|}
\hline \multirow{2}{*}{ Behavioural patterns } & & \multicolumn{3}{|c|}{ Groups } \\
\hline & & Castrated & Docked & Control \\
\hline \multirow{3}{*}{ Comfort behaviour } & Standing idle & $13.0 \pm 2.5^{\mathrm{a}}$ & $11.4 \pm 1.9^{\mathrm{b}}$ & $4.4 \pm 0.6$ \\
\hline & Recumbency & $17.0 \pm 1.6^{\mathrm{a}}$ & $8.7 \pm 0.9^{\mathrm{b}}$ & $9.0 \pm 0.9$ \\
\hline & Sleep & $7.5 \pm 1.2^{\mathrm{a}}$ & $2.9 \pm 0.5^{\mathrm{b}}$ & $8.4 \pm 1.9$ \\
\hline Body care behaviour & Grooming behaviour & $1.0 \pm 0.3$ & $1.5 \pm 0.3$ & $0.2 \pm 0.2$ \\
\hline \multirow{2}{*}{ Eleminativen behaviour } & Defecation & $0.1 \pm 0.1$ & $0 \pm 0.0$ & $0.0 \pm 0.0$ \\
\hline & Urination & $0.2 \pm 0.2$ & $0.2 \pm 0.1$ & $0.4 \pm 0.3$ \\
\hline
\end{tabular}

Results are expressed as means \pm standard error (S.E. Behavioural patterns were recorded as a frequency.

${ }^{\mathrm{a}, \mathrm{b}, \mathrm{c}}$ superscript within rows indicates significant difference at $\mathrm{p}<0.05$.

Table (2): Effect of castration and docking on feeding behaviour in lambs.

\begin{tabular}{|c|c|c|c|}
\hline \multirow{2}{*}{ Behavioural patterns } & \multicolumn{3}{|c|}{ Groups } \\
\hline & Castrated & Docked & Control \\
\hline Suckling & $2.4 \pm 0.6^{b}$ & $1.0 \pm 0.3^{c}$ & $4.8 \pm 0.8^{a}$ \\
\hline Trial suckling & $1.6 \pm 0.6$ & $1.2 \pm 0.6$ & $1.1 \pm 0.3$ \\
\hline Ingestion & $0.0 \pm 0.0$ & $0.0 \pm 0.0$ & $3.4 \pm 0.8^{\mathrm{a}}$ \\
\hline Drinking & $0.5 \pm 0.3$ & $0.2 \pm 0.1$ & $0.1 \pm 0.1$ \\
\hline
\end{tabular}

Results are expressed as means \pm standard error (S.E.)

Behavioural patterns were recorded as a frequency.

a,b,c superscript within rows indicates significant difference at $\mathrm{p}<0.05$

Table (3): Average levels of blood cortisol (ng/ml) in castrated and docked lambs at different intervals

\begin{tabular}{|c|c|c|}
\hline \multirow{2}{*}{ Time interval } & \multicolumn{2}{|c|}{ Groups } \\
\hline & Castrated & Docked \\
\hline Before operation $(-20 \mathrm{~min})$ as a control & $39.5 \pm 10.5^{\mathrm{c}}$ & $43.3 \pm 10.7$ \\
\hline At time of operation & $73.4 \pm 29.2^{b}$ & $57.6 \pm 18.4^{\mathrm{c}}$ \\
\hline One hour after operation & $111.3 \pm 30.8^{\mathrm{a}}$ & $117.1 \pm 39.5^{\mathrm{a}}$ \\
\hline 3hour after operation & $53.1 \pm 22.9^{\mathrm{c}}$ & $87.1 \pm 43.3^{\mathrm{b}}$ \\
\hline
\end{tabular}

Results are expressed as means \pm standard error

${ }^{a, b, c}$ superscript within columns indicates significant difference at $\mathrm{p}<0.05$

(3). The level of blood cortisol was significantly $(\mathrm{p}<0.05)$ increased at the time of operation $(0$ min.) and $1 \mathrm{~h}$ after operation in castrated (73.4 and $111.3 \mathrm{ng} / \mathrm{ml}$ ) and docked (57.6 and 117.1 $\mathrm{ng} / \mathrm{ml}$ ) lambs than before operation (-20 min.) (39.5 and $43.3 \mathrm{ng} / \mathrm{ml}$ ) respectively. At three hours after operation the blood cortisol level was significantly decreased in castrated $(53.1 \mathrm{ng} / \mathrm{ml})$ and docked $87.1 \mathrm{ng} / \mathrm{ml}$ ) lambs as compared to the time of operation but still higher than pretreatment levels. So significantly higher levels of blood cortisol were attained at the time of operation. This result could be explained as the physical injury stimulates the HPA axis leading to acute cortisol responses which after reaching the peak value it falls again by negative feed back mechanism as reported by (Aruthur and Guyton, 1991)

From this study it could be recommended that ram lambs are better not to be castrated if 
they are marketed at a young age (less than 6 months). Furthermore, the decision to castrate ram lambs should be based on the management needs of the shepherd and the demands of the market place. Also castration and docking should be performed at early age of life to decrease stress on the lamb and bleeding incidence.

\section{References}

Appleby, M.C. (1986): Development of sexual and agnostic behaviour in bulls and steers. Appl.Anim.Behav.Sci., 15:190.

Archer, N. (2004): Differences in the acute pain responses of two breeds of lamb following castration and tail docking with the rubber ring method. Animal Welfare 13:135-141.

Aruthur, C. and Guyton, M. D. (1991): Textbook of Medical Physiology $\left(8^{\text {th }}\right.$ ed .) In: Inhibitory effect of cortisol on the hypothalamus and on the Anterior pituitary to cause decreased ACTH secretions,phildelphia, London., pp.650.

Baird, A. N. and Wolfe, D. F. (1998): Castration of the normal male: bulls, rams, and bucks. In: D.F.Wolfe and $\mathrm{H}$. Holl, Editors, Large Animal Urogenital Surgery, Williams \& Wilkins, Baltimore, pp. 295-301.

Cottrell, D. F. and Molony, V. (1995): Afferent activity in the superior spermatic nerve of lambs: the effects of application of rubber castration

Veterinary Research Communications 19:503-515.

Dinniss, A. S.; Mellor, D. J.; Stafford, K. J.; Bruce R. A. and Ward, R. N. (1997): Acute cortisol responses of lambs to castration using a rubber ring and/or a castration clamp with or without local anaesthetic. Newzealand Vet. J., 45: 114-121.

Dinniss, A. S.; Stafford, K. J.; Mellor, D.J.; Todd, S. E.; Bruce R.A. and Ward, R. N. (1999): The behaviour pattern of lambs after castration using a rubber ring and/or castrating clamp with or without local anaesthetic. Newzealand Vet. J., 47: 198-203.

Haddad, S. G.; Husein, M. Q. and Sweidan, R. W. (2006): Effect of castration on growth performance and carcass characteristics of Awassi lambs fed high concentrate diet. Small Rumin. Res., 65:149-153

Kent, J .E.; Molony, V. and Robertson, I. S. (1993): changes in plasma cortisol concentration in lambs of three ages after three methods of castration and tail docking. Res.Vet.Sci., 55:246-251.

Lester, S. J.; Mellor, D .J.; Holmes, R. J.; Ward, R. N. and Stafford, K. J. (1996): Behavioural and cortisol responses of lambs to castration and tailing using different methods. Newzealand Vet J., 44: 45-54.

Marai, I. F. M. and Bahgat, L. B. (2003):Fat-Tailed Sheep Traits as Affected by Docking. Trop. Anim. Hlth Prod. J., 35(4): 351-363.

McGlone, J. J.; Nicholson, R. I.; Hellman, J. M. and Herzog, D. N. (1993): The development of pain in young pigs associated with castration and attempts to prevent castration induced behavioural changes. J.Anim.Sci., 71(6): 1441-1446.

Mellemaa, S. C.; Doherrb, M. G.; Wechslerc, B.; Susann T. and Steinera, A. (2006): Influence of local anaesthesia on pain and distress induced by two bloodless castration methods in young lambs. Veterinary Journal 172(2): 274283.

Mellor, D. J.; Cook, C. J. and Stafford, K.J. (2000): Basic Principles and Implications for Animal Welfare. In:
The Biology of Animal Stress: G.P.Moberg and J.A.Mench, ed. CABI Publishing, U.K. pp. 176.

Mellor, D. J. and Murray, L. (1989): Effects of tail docking and castration on behaviour and plasma cortisol concentrations in young lambs. Res. in Vet. Sci., 46:387391.

Mellor, D. J. and Stafford, K. J. (2000): Acute castration and tailing distress and its alleviation in lambs. Newzealand Vet. J., 48:33-43.

Molony, V. and Kent, J .E. (1997): Assessment of acute pain in farm animals using behavioural and physiological measurements. J. Anim. Sci., 75: 266-272.

Molony, V.; Kent, J. E.; Hosie, B. D. and Graham, M. J. (1997): Reduction in pain suffered by lambs at castration. Vet. J., 153(2):205-213.

Molony,V.; Kent, J.E. and Robertson, I.S.(1995): Assessment of acute and chronic pain after different methods of castration of calves. Appl. Anim.Behav.Sci., 46 (1-2):33-48

Mowlem, A. (1988): Goat Farming $1^{\text {st }}$ ed.Farming Press books, United Kingdom. web page.

Opp, M. R. (1995): Corticotropin-releasing hormone induced involvement in tressor- alterations in sleep and in the regulation of waking. Adv. Neurol., 5: 127-143.

Outhouse, J. B. (1987): Sheep Management Techniques..In: Livestock Management Techniques (ed. Battaglia, R.A. and Mayrose, V.B.). pp. 368-373.

Pawelek, R. and Croney, C. (2003): Animal Welfare Understanding and Addressing Issues Related to the Wellbeing of Livestock. Oregon State University. EM 8826.

Rhodes III, R.C.; Nippo, M. M. and Gross, W. A. (1994): Stress in lambs (Ovis aries) during a routine management procedure: Evaluation of acute and chronic responses. Comp. Biochem. Physiol. Part A: Physiol.,107(1):181-185.

Rolleri, E.; Zannino, M.; Oriandini, S. and Malvano, R. (1976): Analysis of cortisol. Clin.Chim.Acta, 66:319.

Saleem, A. K. Y.; Youssef, M. I. Y.; Mohamed, M. A. and Khattab, N.A. (2003): Behaviour and performance of kids in relation to castration. Suez Canal Vet. Med. J., 1(1):1-8.

Shutt, D.A.; Fell, L.R.; Connell, R. and Bell, A.K. (1988): Stress responses in lambs docked and castrated surgically or by the application of rubber rings. Aust. Vet. J., . 65: 5-7.

Snedecor, G.W. and Cochran, W.G.(1989): Statistical methods. $8^{\text {th }}$ Ed. Iowa State University Press, Ames, IA.

Susan, S. (2007): Docking and Castrating. Sheep 201, A beginner's Guide to Raising Sheep.web page.

Susanne, M.; Mellemaa, S.C. ; Doherrb, M. G. ; Wechslerc, B. and Steinera, A. (2007):Castration of lambs: A welfare comparison of different castration techniques in lambs over 10 weeks of age. Vet.J., 173(3): 554-563.

Thornton, P.D. and Waterman-Pearson, A .E. (1999): Quantification of the pain and distress response to castration in young lambs. Res.Vet. Sci., 66:107-118.

Turner, A. I.; Hosking, B. J.; Parr, R.A. and Tilbrook, A.J. (2006): A sex difference in the cortisol response to tail docking and ACTH develops between 1 and 8 weeks of age in lambs. J. Endocrinol., 188: 443-449.

Wood, G. M.; Molony, V.; Fletwood-Walker, S. M.; Hodgson, J. C. and Mellor, D. J.(1991):Effect of local anesthesia and intravenous naloxone on changes in behaviour and plasma concentration of cortisol produced by castration and tail docking with tight rubber rings in young lambs. Res. Vet. Sci., 51:193-199. 


\section{تاثير الخصى وقطع الذيل فى الحملان على سلوك الحفاظ على الحياة ومستوى هرمون الكورتيزول}

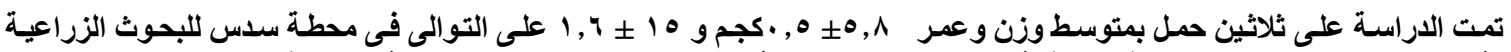

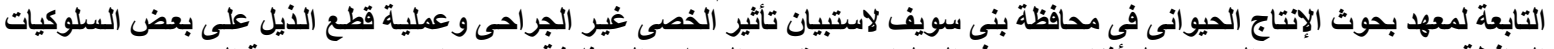

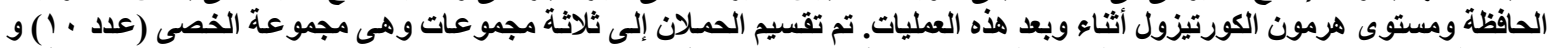

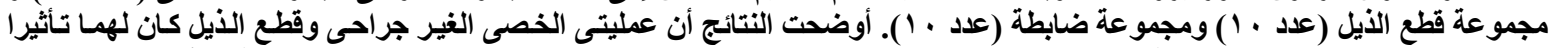

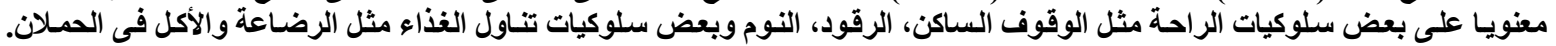

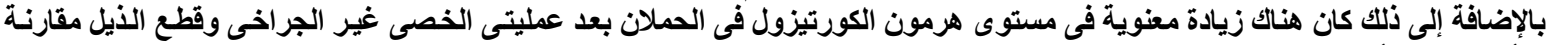

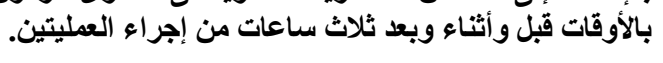

